\title{
Analisis Pengaruh Infrastruktur terhadap Perdagangan dan Keberhasilan Integrasi Ekonomi Indonesia Ke ASEAN+3
}

\author{
Piety Yusyahbella ${ }^{*}$, Arief Daryanto ${ }^{2}$, Tanti Novianti ${ }^{3}$ \\ ${ }^{1,3}$ Departemen Ilmu Ekonomi, Fakultas Ekonomi dan Manajemen, Institut Pertanian Bogor, \\ ${ }^{2}$ Sekolah Bisnis, Institut Pertanian Bogor, Indonesia \\ "Korespondensi: pietyyusyah@gmail.com
}

[diterima: November 2019- revisi: November 2019-diterbitkan daring: Desember 2019]

\begin{abstract}
ABSTRAK
Nilai ekspor dan impor Indonesia ke negara ASEAN+3 mencapai $52.3 \%$ dan $62.73 \%$ dari total perdagangan Indonesia ke dunia. Infrastruktur mempunyai peran vital dalam menunjang kelancaran perdagangan. Selama periode 2007-2017 arus bongkar-muat barang Indonesia didominasi oleh moda transportasi laut yaitu 96\%. Keadaan infrastruktur Indonesia jauh lebih rendah dibanding negara ASEAN+3 lainnya terutama dalam hal infrastruktur laut (infrastruktur fisik) dan penggunaan internet (infrastruktur non fisik). Tujuan penelitian ini adalah untuk melihat gambaran perdagangan Indonesia dengan ASEAN+3, menganalisis faktor-faktor yang memengaruhi perdagangan Indonesia ke ASEAN+3 dan menganalisis rasio keberhasilan Indonesia ke ASEAN+3. Penelitian ini menggunakan metode analisis deskriptif, gravity model dan rasio keberhasilan. Variabel yang digunakan adalah gross domestic product (GDP), jarak ekonomi, container port traffic (CPT), air traffic fraigh (ATF), pengguna internet (IU) dan pengguna telepon genggam (MP). Hasilnya menunjukkan bahwa Perdagangan Indonesia ke negara ASEAN+3 cukup tinggi. Sektor non migas masih menjadi penyumbang ekspor terbesar dari total ekspor. Republik Rakyat Tiongkok (RRT) merupakan negara tujuan ekspor dan juga negara asal impor dengan nilai terbesar. ATF tidak memengaruhi ekpor dan impor Indonesia sedangkan variabel lainnya berpengaruh signifikan positif kecuali PDB per kapita yang berpengaruh signifikan negatif terhadap ekspor. Rasio keberhasilan ekspor dan impor Indonesia ke ASEAN+3 belum tercapai seutuhnya.
\end{abstract}

Kata kunci: ASEAN+3, gravity model, infrastruktur, rasio keberhasilan

\section{ABSTRACT}

Export and import from Indonesia to ASEAN+3 countries reached $52.3 \%$ and $62.37 \%$ of the total trade of Indonesia to the world. Infrastructure played a vital role in supporting successful trade. During the period 2007-2017, loading and discharging flows of Indonesian goods were dominated by sea transportations modes by $96 \%$. Indonesia's infrastructure is far lower than other ASEAN+3 countries especially marine infrastructure and the internet users. The purpose of this study is to describe Indonesia's trade with ASEAN+3 countries, to the determinant that influence Indonesia's trade into the ASEAN+3 and to analyze the success ratio of Indonesia to ASEAN+3. This study is using descriptive analysis, gravity model and success ratio method. This study is using descriptive analysis, gravity model and success ratio method. The variables used in this study are the gross domestic product per capita, economic distance, air transport freight, container port traffic, internet user and mobile phone. The results show that Indonesia's highest export - import is with China. ATF has no significant effect on both export and import, while other variables give a significant positive effect except GDP per capita that has a significant negative effect to export. The success of economic integration for Indonesia's exports and imports into the ASEAN+3 region has not been fully achieved.

Keywords: ASEAN+3, infrastructure, gravity model, success ratio JEL classification: F15, F53, H54 


\section{PENDAHULUAN}

Liberalisasi perdagangan yang akses informasi yang semakin mudah membuat aliran barang dan jasa menjadi lebih cepat dan terbuka. Perkembangan perekonomian dunia telah membuka akses kerjasama yang luas sehingga terbentuk hubungan perdagangan dan investasi antar negara. Untuk mendapatkan keuntungan dan meningkatkan nilai perdagangan, negaranegara di dunia membentuk kawasan integrasi ekonomi yang mempunyai manfaat berupa terciptanya efisiensi ekonomi dan berkembangnya industri lokal. Association of South East Asian Nations (ASEAN) merupakan organisasi kerja sama di kawasan Asia Tenggara yang didirikan pada tanggal 8 Agustus 1967 melalui deklarasi Bangkok. Tahun 1997 terbentuk kerjasama ASEAN+3 yang melibatkan tiga negara di wilayah Asia Timur yaitu RRT, Jepang dan Korea Selatan. Kerjasama ini dibentuk sebagai akibat semakin meningkatnya kebutuhan energi baik di tingkat regional maupun tingkat dunia. Prinsip dasar integrasi ekonomi adalah mengurangi atau menghilangkan hambatan perdagangan di antara negara anggota. Ekonomi beberapa negara anggota ASEAN+3 mengalami perkembangan yang cukup pesat dalam 25 tahun terakhir.

Ekonomi beberapa negara anggota ASEAN+3 mengalami perkembangan yang cukup pesat dalam 25 tahun terakhir. Nilai GDP negara ASEAN+3 hampir selalu meningkat setiap tahunnya. Tahun 2007 total GDP ASEAN+3 bernilai 13.16 miliar USD dari total GDP dunia yaitu 63.19 miliar USD. Tahun 2017 total GDP ASEAN+3 meningkat menjadi 20.45 miliar USD dari total GDP dunia yaitu 80.07 miliar USD atau $25.5 \%$ dari total GDP dunia. Besarnya nilai GDP negara ASEAN+3 membuat kerjasama ekonomi dikawasan ini akan bernilai strategis dan menguntungkan untuk Indonesia. Perdagangan Indonesia baik ekspor maupun impor ke negara ASEAN+3 sangat tinggi meskipun berfluktuatif. Tahun 2007 ekspor Indonesia ke wilayah ASEAN+3 bernilai 57.96 miliar USD (50.7\%) dari total nilai ekspor Indonesia ke dunia sebesar 114.1 miliar USD. Impor Indonesia tahun 2007 dari wilayah ASEAN+3 bernilai 40.67 miliar USD $(54.41 \%)$ dari total nilai impor Indonesia ke dunia yaitu 74.47 miliar USD. Tahun 2017 ekspor Indonesia ke ASEAN+3 meningkat dengan nilai 88.35 miliar USD $(52.33 \%)$ dari nilai impor Indonesia ke dunia yaitu 168.81 miliar USD dan impornya meningkat lebih tinggi dengan nilai 98.49 miliar USD (62.77\%) dari total impor Indonesia ke dunia yaitu 156.9 miliar USD (World Bank, 2019).

Infrastruktur menjadi sektor penting dan vital dalam perekonomian suatu negara terutama dalam menunjang distribusi barang ekspor dan impor. Tingginya nilai perdagangan Indonesia memberikan dampak langsung terhadap peningkatan arus barang dari tahun 2007 - 2017. Bongkar muat barang untuk kegiatan ekspor dan impor di Indonesia masih didominasi oleh jalur laut yaitu melalui pelabuhan sebesar $96.21 \%$, lalu disusul melalui jalur darat melalui kereta api sebesar $3.73 \%$ dan terakhir jalur udara yaitu melalui bandara sebesar 0.05\% (BPS, 2019).

Pemerintah melalui Badan Perencanaan Nasional merencanakan pembangunan infrastruktur tahun 2015 - 2019 dengan isu strategis berupa peningkatan infrastruktur dasar, peningkatan ketahanan air, pangan dan energi, penguatan konektivitas nasional, pengembangan transportasi massal perkotaan dan peningkatan efektivitas dan efisiensi pembiayaan penyediaan infrastruktur. Keadaan infrastruktur Indonesia pada tahun 2014 untuk konektivitas pada kemantapan jalan nasional masih pada kondisi 94\%, waktu tempuh rata-rata (koridor utama) 2.7 jam/100 km dan rasio biaya logistik terhadap GDP sebesar 23.5\%. Pemerintah menetapkan target untuk meningkatkan kondisi infrastruktur Indonesia di tahun 2019 menjadi konektivitas pada kemantapan jalan nasional pada kondisi $100 \%$, waktu tempuh rata-rata (koridor utama) turun dengan angka $2.2 \mathrm{jam} / 100 \mathrm{~km}$ dan rasio biaya logistik terhadap gross domestic product (GDP) turun dengan angka 19.2\% (Bappenas, 2019).

Semakin baik kualitas infrastruktur suatu negara maka biaya perdagangan baik ekspor maupun impor akan semakin kecil sehingga volume ekspor dan daya saingnya akan meningkat. Kendala yang terjadi adalah pengembangan infrastruktur di Indonesia tidak sejalan dengan kecepatan pertumbuhan ekonomi yang kuat. 
Biaya logistik yang sangat tinggi membuat daya saing menjadi rendah. Menurut Salvatore (1997) biaya transportasi memberikan pengaruh langsung yang sangat besar terhadap perdagangan internasional, yaitu dengan meningkatkan harga atau komoditi yang diperdagangkan, baik untuk negara pengekspor ataupun bagi negara pengimpor. Biaya pengangkutan merupakan hambatan dalam setiap pergerakan barang dan jasa, maka unsur biaya ini memiliki implikasi penting terhadap mekanisme perekonomian terbuka.

Daryanto dan Sahara (2016) menyebutkan bahwa Indonesia dikenal sebagai negara dengan biaya logistik yang tinggi, dari tahun 2004 hingga 2011 rasio biaya logistik terhadap PDB berada di atas $20 \%$, cukup tinggi jika dibandingkan dengan negara ASEAN+3 lainnya, seperti RRT dengan rasio $16 \%$ dan Malaysia dengan rasio $15 \%$. Berdasarkan global competitiveness report tahun 2017 peringkat Indonesia naik 4 (empat) poin menjadi peringkat ke-36 dari sebelumnya ditahun 2016 berada di peringkat 41 dari 137 negara. Keadaan infrastruktur Indonesia secara keseluruhan berada diperingkat ke-68 dari 137 negara dengan nilai 4.1. Diantara empat infrastruktur fisik peringkat infrastruktur pelabuhan adalah yang paling rendah yaitu peringkat ke-72 dengan nilai 4.0, infrastruktur jalan peringkat ke-64 dengan nilai 4.1, infrastruktur bandara peringkat ke-51 dengan nilai 4.8 dan infrastruktur kereta yang paling tinggi yaitu peringkat ke-30 dengan nilai 4.2. Keadaan infrastruktur non fisik Indonesia yaitu informasi dan teknologi komunikasi (ICT) untuk pengguna internet berada diperingkat ke-109 dengan nilai 25.4 dan penggunaan telepon genggam berada diperingkat ke-56 dengan nilai 67.3. Jika dibandingkan dengan anggota ASEAN+3 lainnya infrastruktur Indonesia masih rendah. Rendahnya kualitas pelabuhan Indonesia disebabkan oleh masalah kualitas infrastruktur dan suprastruktur, biaya logistik yang tinggi, biaya pengangkutan mahal, minimnya sumberdaya, dan pengurusan dokumen kepabeanan yang lama.

Kerjasama ASEAN+3 diharapkan dapat mendorong pertumbuhan ekonomi dan memberikan nilai surplus pada neraca perdagangan negara anggota. Namun sering kali dalam hubungan dagang ada pihak yang lebih diuntungkan sehingga manfaat ekonomi yang diterima tidak sama. Indonesia menghadapi tantangan besar berupa Indonesia harus meningkatkan efisiensi dan efektifitas produksi, menciptakan iklim usaha yang kondusif, menerapkan ketentuan dan peraturan investasi yang transparan, efisien dan ramah dunia usaha serta meningkatkan penguasaan teknologi informasi dan komunikasi termasuk promosi pemasaran dan lobby. Melalui kerjasama ASEANRRT Free Trade Area(ACFTA), Asean-Korea Free Trade Area (AKFTA) dan ASEAN-Japan Comprehensive Economic Partnership (AJCEP), Indonesia menerima beberapa manfaat berupa penurunan tarif, terbukanya akses pasar ke negara anggota, adanya transfer teknologi, dsb. Agar manfaat ekonomi dapat dirasakan secara maksmimal tentunya harus diimbangi dengan kondisi infrastruktur Indonesia. Ekspor, impor dan neraca perdagangan sektor industri Indonesia ke ASEAN+3 meningkat dari tahun 2006 sampai tahun 2011 sejak adanya kerjasama FTA ASEAN+3 (Kemenperin, 2018).

Besarnya akses pasar dan tingginya nilai perdagangan Indonesia ke ASEAN+3 harus dikaji lebih lanjut. Keberhasilan kerjasama antar dua negara yang berdagang juga harus dilihat mengingat banyaknya kesepakatan dan implementasi kebijakan yang telah dilaksanakan dalam kesepakatan dagang maka harus diobservasi apakah kesepakatan dan kebijakan tersebut memberikan dampak terhadap kondisi perdagangan kedua negara atau tidak memberikan dampak apapun. Idealnya integrasi ekonomi bersifat global dan berjalan tanpa hambatan, namun pada kenyataannya fair trade sulit tercapai dan diwujudkan. Berdasarkan uraian di atas, maka tujuan penelitian adalah (1) mendeskripsikan gambaran umum perdagangan Indonesia dengan negara-negara ASEAN+3; (2) menganalisis faktor-faktor infrastruktur yang memengaruhi perdagangan Indonesia ke ASEAN+3; dan (3) menganalisis tingkat keberhasilan integrasi ekonomi Indonesia ke ASEAN+3. 


\section{TINJAUAN PUSTAKA}

Balassa membagi tahap integrasi menjadi enam bagian yaitu: (i) Preferential Trading Area (PTA); (ii) Free Trade Area (FTA); (iii) Custom Union; (iv) Common Market; Economic Union (EU); dan (vi) Total Economic Integration. Secara teoritis, tahapan integrasi Balassa menunjukkan bahwa semakin tinggi tahapan integrasi ekonomi, semakin kompleks persyaratan kebijakan yang diperlukan. Integrasi ekonomi mengarah pada peningkatan spesialisasi produksi yang didasarkan pada keuntungan komparatif setiap negara sehingga berdampak pada meningkatnya kesejahteraan negara anggota secara menyeluruh (Ridwan, 2011).

Pembangunan infrastruktur adalah bagian penting dari pembangunan nasional. Infrastruktur merupakan roda penggerak pertumbuhan ekonomi. World Bank membagi infrastruktur menjadi tiga yaitu; (1) Infrastruktur ekonomi, merupakan aset fisik yang diperlukan untuk menunjang aktivitas ekonomi baik dalam produksi maupun konsumsi final, meliputi public utilities (tenaga, telekomunikasi, air minum, sanitasi dan gas), public work (jalan, bendungan, kanal, saluran irigasi dan drainase) serta sektor transportasi (jalan, rel kereta api, angkutan pelabuhan, lapangan terbang dan sebagainya), (2) Infrastruktur sosial, merupakan aset yang mendukung kesehatan dan keahlian masyarakat, meliputi pendidikan (sekolah dan perpustakaan), kesehatan (rumah sakit dan pusat kesehatan), perumahan dan rekreasi (taman, museum dan lain-lain), (3) Infrastruktur administrasi/institusi, meliputi penegakan hukum, kontrol administrasi dan koordinasi serta kebudayaan. Infrastruktur transportasi mampu menciptakan mobilitas sosial dan ekonomi masyarakat (barang, manusia/penumpang), dan menghubungkan sumber daya dan hasil produksi ke pasar. Infrastruktur transportasi berdampak pada kesejahteraan masyarakat seperti perdagangan antar wilayah, perluasan pasar, terciptanya kompetisi, penyebaran pengetahuan dan teknologi, meningkatkan aksesibilitas pendudukan terhadap sarana kesehatan dan pendidikan, yang pada akhirnya akan meningkatkan kualitas kesehatan dan pendidikan (World Bank, 2009).
Nordas dan Piermartini (2004) melakukan penelitian tentang peran kualitas infrastruktur dalam kinerja perdagangan menggunakan gravity model. Penelitian ini melihat kualitas infrastruktur dari sisi (jalan, pelabuhan, bandara, telekomunikasi dan waktu yang dibutuhkan untuk custom clearance dalam perdagangan bilateral, perdagangan sektor otomotif dan sektor tekstil dan produk tekstil (TPT). Hasilnya adalah jarak tidak menjadi hambatan perdagangan dengan adanya perkembangan transportasi dan infrastruktur komunikasi, kualitas infrastruktur merupakan faktor penting dalam kinerja perdagangan, efisiensi pelabuhan (port efficiency) mempunyai dampak paling besar dalam perdagangan dibandingkan indikator lainnya, ketepatan waktu dan telekomunikasi lebih berdampak pada daya saing ekspor otomotif dan TPT.

Ismail dan Mahyideen (2015) meneliti dampak infrastruktur terhadap perdagangan dan pertumbuhan ekonomi di beberapa negara Asia menggunakan metode gravity model. Penelitian ini membagi infrastruktur menjadi dua kategori yaitu infrastruktur fisik dan infrastruktur sosial. Variabel infrastruktur yang digunakan adalah panjang jalan, jalur kereta api, efisiensi pelabuhan, logistik, bandara dan informasi dan teknologi komunikasi (ICT). ICT sendiri digambarkan melalui pengguna internet, telepon genggam, jaringan telepon dan akses internet. Variable jarak, GDP, dummy kesamaan bahasa dan dummy pendapatan juga digunakan untuk mengestimasi dampak pegaruh infrastruktur. Hasil penelitian menunjukkan panjang jalan, efisiensi pelabuhan, dummy kesamaan bahasa, dummy pendapatan dan ICT berdampak positif terhadap perdagangan di beberapa negara Asia. Jarak berpengaruh tidak signifikan dalam penelitian ini yang artinya jarak tidak lagi menjadi hambatan perdagangan. Peningkatan di seluruh infrastruktur transportasi akan meningkatkan arus perdagangan

Fejzic dan Covrk (2016) meneliti dampak infrastruktur dan biaya transportasi dalam perdagangan Bosnia dan Herzegovina menggunakan pendekatan gravity model. Penelitan dilakukan untuk tahun 2005-2014. Variabel yang digunakan adalah jarak, tarif, kualitas logistik, dummy kesamaan bahasa, 
dummy sejarah, dummy landlocked, kualitas infrastruktur transportasi yang digambarkan dengan panjang jalan, panjang rel kereta, bandara, dan ICT (pengguna internet dan telepon genggam). Hasilnya menunjukkan bahwa kualitas infrastruktur dan logistik adalah faktor penting dalam kinerja perdagangan, jarak tidak lagi berpengaruh signifikan ketika ada kualitas infrastruktur, perdagangan menjadi dua kali lebih besar ketika Bosnia dan Herzegovina berdagang dengan negara yang mempunyai kesamaan bahasa. Peningkatan kualitas infrastruktur sebesar $1 \%$ akan meningkatkan perdagangan sebesar $2.83 \%$.

Ozcan B (2017) meneliti dampak informasi dan teknologi komunikasi (ICT) terhadap perdagangan internasional negara Turki dengan negara mitranya menggunakan gravity model. Sampelnya menggunakan 34 negara dalam kurun waktu tahun 2000-2014. Variabel yang digunakan untuk mengestimasi model adalah GDP, populasi, jarak, dummy bahasa, dummy sejarah, dummy landlocked, dan dummy border. Hasilnya menunjukkan bahwa ICT berdampak signifikan positif terhadap volume ekspor dan impor. Secara kuantitatif ICT mempunyai dampak yang lebih besar terhadap impor daripada ekspor. Hasilnya mengindikasikan bahwa turunnya biaya perdagangan seperti biaya transportasi, biaya informasi dan komunikasi, biaya masuk pasar baik di Turki maupun di negara mitra dagang dapat menstimulus arus perdagangan.

Daryanto dan Sahara (2016) meneliti dampak kinerja logistik terhadap ekspor pertanian Indonesia menggunakan metode gravity model. Objek penelitian mencakup 21 negara dengan jangka waktu tahun 2005-2013. Variabel yang digunakan adalah indeks kinerja logistik (LPI), GDP, jarak, tarif, populasi, informasi teknologi, indeks pemerintahan, dan biaya transaksi. Hasilnya menyebutkan bahwa LPI adalah variabel yang memberikan dampak paling besar dalam perdagangan. Indonesia dikenal sebagai negara dengan biaya logistik yang tinggi, dari tahun 2004 hingga 2011 rasio biaya logistik terhadap PDB berada di atas $20 \%$. Komponen biaya logistik terdiri dari biaya transportasi, persediaan dan administrasi. Diantara biayabiaya tersebut, biaya transportasi memberikan kontribusi terbesar dalam biaya logistik (sekitar 12\% pada periode 2004-2011). ICT juga berpengaruh signifikan positif terhadap ekspor pertanian Indoneia. Peningkatan $1 \%$ pada ICT akan meningkatkan ekspor sebesar $17.7 \%$.

\section{METODE}

\section{Jenis dan Sumber Data}

Penelitian ini menggunakan data sekunder dalam bentuk time series dari tahun 2007 hingga 2017 dan cross section 12 negara ASEAN+3 yaitu yaitu Indonesia, Malaysia, Singapura, Thailand, Filipina, Vietnam, Brunei Darusalam, Myanmar, Kamboja, RRT, Jepang dan Korea Selatan. Data yang digunakan dalam penelitian ini adalah GDP per kapita negara tujuan, jarak ekonomi, container port traffic (CPT) Indonesia, air traffic freight (ATF) Indonesia, pengguna internet negara tujuan dan pengguna telepon genggam negara tujuan. Data yang digunakan berasal dari beberapa sumber, yaitu United Nations Commodity Trade Statistics Database (UN Comtrade), World Bank,dan Centre d'Etudes Prospectives et d'Informations Internationales (CEPII).

\section{Metode Analisis dan Pengolahan Data}

\section{Gravity Model}

Analisis faktor yang memengaruhi ekspor dan impor dilakukan dengan metode gravity model. Gravity model merupakan model ekonomi yang digunakan untuk menjelaskan hubungan perdagangan antar negara. Model ini didasarkan atas teori Sir Isaac Newton tentang gravitasi. Model ini memperkirakan bahwa volume perdagangan antara kedua negara berhubungan lurus dengan pendapatan masing-masing negara tersebut, dan berhubungan terbalik dengan hambatan perdagangan negara. Metode ini pertama kali digunakan dalam analisis perdagangan internasional oleh Jan Tinberger pada tahun 1962 untuk menganalisis aliran perdagangan antara negara-negara Eropa (Head, 2003).

$$
\begin{aligned}
\operatorname{lnXijt}= & \beta 0+\beta 1 \operatorname{lnGDP}_{\mathrm{j}} \mathrm{t}+\beta 2 \ln \operatorname{lnIST}_{\mathrm{ij}} \mathrm{t}+\beta 3 \\
& \ln \mathrm{ATF}_{\mathrm{i}} \mathrm{t}+\beta 4 \operatorname{lnCPT}_{\mathrm{i}} \mathrm{t}+\beta 5 \operatorname{lnMP}_{\mathrm{j}} \mathrm{t}+\varepsilon_{\mathrm{ij}} \mathrm{t}
\end{aligned}
$$




$$
\begin{aligned}
& \operatorname{lnMijt}=\alpha 0+\alpha 1 \operatorname{lnGDP}_{\mathrm{j}} \mathrm{t}+\alpha 2 \operatorname{lnDIST} \mathrm{ij}_{\mathrm{ij}} \mathrm{t}+\alpha 3 \\
& \ln \mathrm{ATF}_{\mathrm{i}} \mathrm{t}+\alpha 4 \operatorname{lnCP} \mathrm{T}_{\mathrm{i}} \mathrm{t}+\alpha 5 \mathrm{IU}_{\mathrm{j}} \mathrm{t}+\alpha 7 \\
& \operatorname{lnMP} P_{j} t+\varepsilon i j t
\end{aligned}
$$

Keterangan:

$$
\begin{aligned}
& \beta 0, \alpha 0=\text { intersep } \\
& \beta \mathrm{n}, \alpha \mathrm{n}, \quad=\text { parameter masing-masing variabel } \\
& \text { yang akan diuji secara statistik dan } \\
& \text { ekonometrik } \\
& \mathrm{t}=(1, \ldots, \mathrm{T}) \text { mulai tahun 2007-2017 } \\
& \mathrm{i}, \mathrm{j}=(1, \ldots, \mathrm{N}) \text { perdagangan bilateral } \\
& \text { negara } \mathrm{i} \text { dan } \mathrm{j} \\
& \ln \mathrm{X}_{\mathrm{ij}} \mathrm{t}=\text { nilai total ekspor Indonesia } \mathrm{ke} \\
& \text { negara anggota ASEAN+3 pada } \\
& \text { tahun t (USD) } \\
& \ln \mathrm{M}_{\mathrm{ij}} \mathrm{t}=\text { nilai total impor Indonesia dari } \\
& \text { negara anggota ASEAN+3 pada } \\
& \text { tahun } \mathrm{t} \text { (USD) }
\end{aligned}
$$

2. Rasio Keberhasilan

Nilai rasio keberhasilan integrasi ekonomi pada perdagangan diperoleh melalui perhitungan yang digunakan oleh Salim dan Kabir (2010). Estimasi keberhasilannya menggunakan rasio dari dua variabel yaitu nilai perdagangan aktual dan potensial. Dalam penelitian ini, nilai perdagangan aktual menggunakan data nilai total ekspor dan impor yang diperoleh dari $U N$ Comtrade, sedangkan untuk nilai perdagangan potensialnya diperoleh dengan mensubtitusi seluruh data ke dalam gravity model untuk melihat the fitted trade flows-nya. The fitted trade flows dipakai sebagai aliran perdagangan potensial. Rasio dari keberhasilan integrasi ekonomi regional pada perdagangan dijabarkan dalam persamaan sebagai berikut:

$$
\text { Rasio Keberhasilan }=\frac{\text { Perdagangan Aktual }}{\text { Perdagangan Potensial }}
$$

Jika rasio keberhasilan lebih besar dari 1 (satu) maka keberhasilan integrasi ekonomi regional ASEAN telah tercapai. Sebaliknya, jika rasio keberhasilan kurang dari 1 (satu) maka keberhasilan integrasi ekonomi regional ASEAN belum tercapai.

\section{HASIL DAN PEMBAHASAN}

Gambar 1 menginformasikan bahwa perdagangan Indonesia ke negara ASEAN+3 mencapai $57 \%$ sedangkan sisanya yaitu $43 \%$ adalah perdagangan Indonesia dengan negara diluar ASEAN+3. Pada tahun 2017 neraca perdagangan Indonesia surplus sebesar 11.84 miliar USD. Perdagangan Indonesia yang paling tinggi nilainya adalah dengan RRT, Jepang dan Singapura sedangkan yang paling rendah nilainya adalah perdagangan dengan Myanmar, Brunei Darussalam dan Laos. Ekspor dan impor komoditi dengan Pos Tarif/HS 85 sangat mendominasi dengan persentase masing-masing $22 \%$ dan $22.6 \%$. Ekspor Indonesia menurut sektor sepanjang tahun 2017 paling tinggi disumbang oleh sektor industri pengolahan dengan nilai 125.1 miliar USD, sektor tambang dan lainnya dengan nilai 24.31 miliar USD, sektor migas dengan nilai 15.74 miliar USD dan sektor pertanian dengan nilai 3.67 miliar USD. Menurut provinsi asal barang, ekspor Indonesia terbesar pada Januari-November 2017 berasal dari Jawa Barat dengan nilai 26.89 miliar USD (17.47\%), diikuti Jawa Timur 16.97 miliar USD (11.03\%) dan Kalimantan Timur 16.02 miliar USD (10.41\%). Pada periode Januari-November 2017, RRT merupakan negara tujuan ekspor terbesar dengan nilai 19129 juta USD dan Jepang diurutan ke-2 dengan nilai 13221.9 juta USD. 


\section{Perkembangan Perdagangan Bilateral Indonesia dengan ASEAN+3}

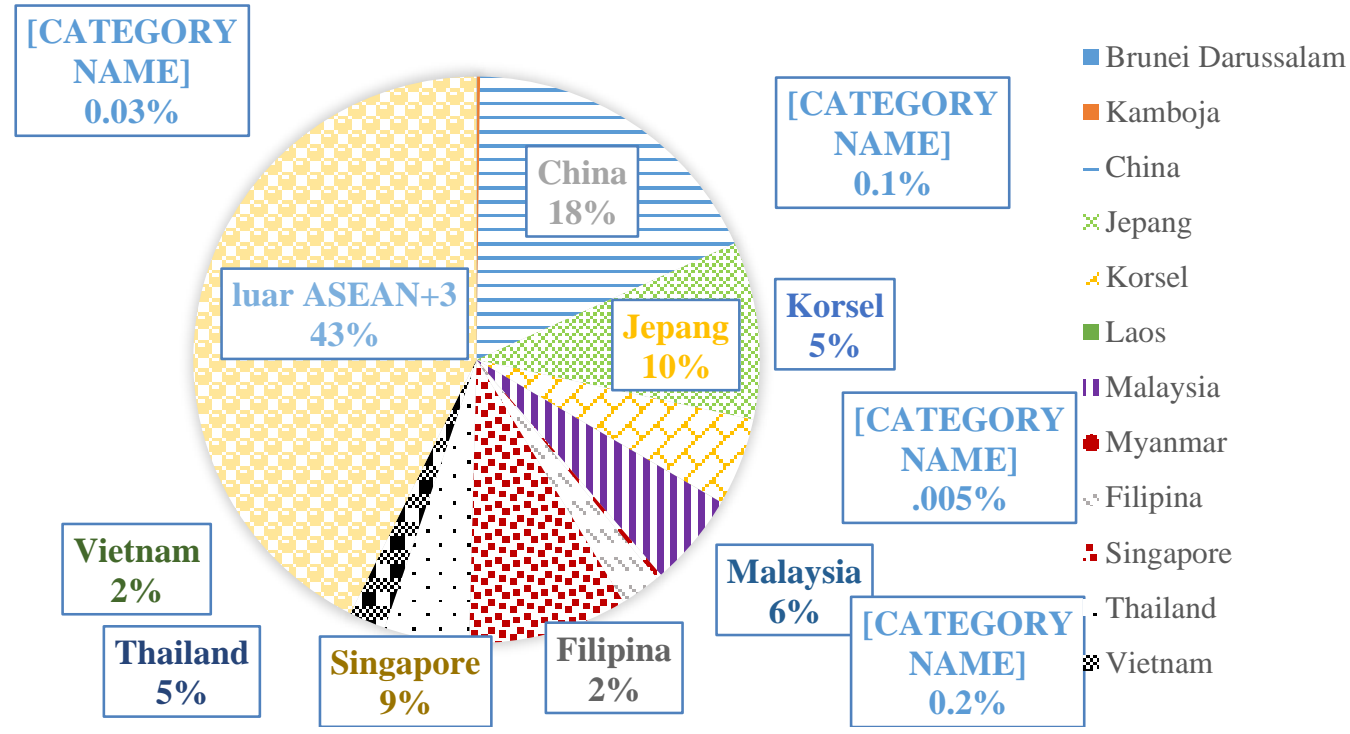

Sumber: UN Comtrade (2018)

Gambar 1. Neraca Perdagangan Indonesia Menurut Negara Tujuan Tahun 2017

Nilai impor komulatif Januari-November 2017 sebesar 141.88 miliar USD atau meningkat $15.47 \%$ dibandingkan periode yang sama tahun sebelumnya. Peningkatan terjadi pada impor migas dan nonmigas masing-masing $27.85 \%$ dan $13.48 \%$. Salah satu faktor yang mendorong tingginya impor di wilayah intra ASEAN+3 ini karena meningkatnya impor dari RRT sebesar $8.2 \%$. Komoditi yang paling banyak diimpor dikawasan intra-ASEAN+3 adalah barang dengan pos tarif/HS 85 (electrical machinery and equipment and parts thereof; sound recorders and reproducers; television image and sound recorders and reproducers, parts and accessories of such articles), pos tarif/HS 27 (mineral fuels, mineral oils and products of their distillation; bituminous substances; mineral waxes), pos tarif/HS 84 (nuclear reactors, boilers, machinery and mechanical appliances; parts thereof), pos tarif/HS 87 (vehicles; other than railway or tramway rolling stock, and parts and accessories thereof), pos tarif/HS 39 (plastics and articles thereof), pos tarif/HS 71 (natural, cultured pearls; precious, semi-precious stones; precious metals, metals clad with precious metal, and articles thereof; imitation jewellery; coin), pos tarif/HS 90 (electrical machinery and equipment and parts thereof; sound recorders and reproducers; television image and sound recorders and reproducers, parts and accessories of such articles), pos tarif/HS 29 (organic chemicals), pos tarif/HS 15 (animal or vegetable fats and oils and their cleavage products; prepared animal fats; animal or vegetable waxes), pos tarif/HS 73 (iron or steel articles) dan pos tarif/HS 72 (iron and steel).

Komoditi yang paling banyak diekspor dikawasan intra-ASEAN+3 adalah barang dengan pos tarif/HS 27 (mineral fuels, mineral oils and products of their distillation; bituminous substances; mineral waxes), pos tarif/HS 87 (vehicles; other than railway or tramway rolling stock, and parts and accessories thereof), pos tarif/HS 84 (nuclear reactors, boilers, machinery and mechanical appliances; parts thereof), pos tarif/HS 85 (electrical machinery and equipment and parts thereof; sound recorders and reproducers; television image and sound recorders and reproducers, parts and accessories of such articles), pos tarif/HS 73 (iron or steel articles), pos tarif/HS 71 (natural, cultured pearls; precious, semi-precious stones; precious metals, metals clad with precious metal, and articles thereof; imitation jewellery; coin), pos tarif/HS 39 (vehicles; other than railway or tramway rolling stock, and parts and accessories thereof), pos tarif/HS 90 (electrical machinery and equipment and parts thereof; sound recorders and reproducers; television image and sound recorders and reproducers, parts and 
accessories of such articles) dan pos tarif/HS 94 (furniture; bedding, mattresses, mattress supports, cushions and similar stuffed furnishings; lamps and lighting fittings, n.e.c.; illuminated signs, illuminated name-plates and the like; prefabricated buildings). Pemberlakuan
AFTA, AEC, AKFTA, AJCEP, ACFTA, dan perjanjian lainnya adalah salah satu faktor yang berpengaruh terhadap hal tersebut karena dengan adanya AFTA hambatan-hambatan perdagangan antar negara ASEAN menjadi hilang sehingga perdagangan antar anggota dapat ditingkatkan.

Tabel 1. Perdagangan Indonesia dengan negara ASEAN+3 tahun 2017 (dalam juta USD)

\begin{tabular}{lrrrl}
\hline \multicolumn{1}{c}{ Negara } & Ekspor & Impor & $\begin{array}{c}\text { Neraca } \\
\text { Perdagangan }\end{array}$ & Keterangan \\
\hline Jepang & 17790 & 15240 & 2550 & Surplus \\
RRT & 23049 & 35766.83 & -12718 & Defisit \\
Singapura & 12767 & 16888 & -4121 & Defisit \\
Malaysia & 8467 & 8858 & -391 & Defisit \\
Korea Selatan & 8186 & 8122 & 64 & Surplus \\
Thailand & 6462 & 9281 & -2819 & Defisit \\
Filipina & 6627 & 859 & 5768 & Surplus \\
Vietnam & 3587 & 3228 & 359 & Surplus \\
Myanmar & 830 & 146 & 684 & Surplus \\
Kamboja & 514 & 28 & 486 & Surplus \\
Brunei Darussalam & 65 & 43 & 22 & Surplus \\
\hline
\end{tabular}

Sumber: UN Comtrade (2018)

Tabel 1 menginformasikan bahwa pada tahun 2017 neraca perdagangan Indonesia mengalami surplus dan defisit dengan negara ASEAN+3. Nilai surplus neraca perdagangan terbesar yaitu 5768 juta USD dicapai pada perdagangan Indonesia dengan Filipina, sedangkan nilai defisit neraca perdagangan terbesar yaitu 12718 juta USD terjadi pada perdagangan Indonesia dengan RRT. Tingginya nilai impor Indonesia dari RRT didorong karena tingkat produksi manufaktur RRT adalah yang terbesar didunia dan barang yang berasal dari RRT mempunyai daya saing tinggi dengan harga yang murah.

Komoditi unggulan ekspor dan impor dari setiap negara ASEAN+3 berbeda-beda. Negaranegara anggota ASEAN+3 merupakan negara yang beragam dalam hal faktor endowments, pengembangan sumber daya manusia, kemampuan teknologi, dan produktivitas. Keragaman tercermin dalam pola ekspor dan impor yang berbeda di seluruh negara anggota. Masing-masing negara memiliki keunggulan komparatifnya sendiri seperti bahan bakar dan mineral (Brunei Darussalam, Indonesia, Malaysia, dan Myanmar), produk pertanian (Indonesia, Myanmar, dan Vietnam), produk manufaktur (Kamboja, Malaysia, Filipina, Singapura, Thailand, dan Vietnam, RRT), dan jasa komersial (Filipina dan Singapura). Oleh karena itu hampir seluruh negara di dunia menjadikan ASEAN+3 sebagai mitra dagangnya (Kawai dan Naknoi, 2015).

\section{Perkembangan GDP Per Kapita ASEAN+3 Tahun 2007-2017}

GDP per kapita menggambarkan tingkat kesejahteraan serta kemampuan ekonomi ratarata setiap penduduk di negara tersebut. Tahun 2017 GDP negara RRT mencapai 12143.2 miliar USD dimana angka ini hampir tiga kali lebih besar daripada GDP negara Jepang ditahun yang sama yaitu 4859 miliar USD. Sebagai salah satu negara yang mempunyai populasi paling banyak didunia yaitu 1.38 miliar jiwa, hal ini membuat GDP perkapita RRT menjadi kecil. Negara Singapura, Korea Selatan, Brunei Darussalam dan Jepang memiliki nilai GDP per kapita lebih dari 25 ribu USD, nilai tersebut sangat besar jika dibandingkan dengan negara lainnya seperti Myanmar, Kamboja dan Vietnam. GDP perkapita Brunei cenderung mengalami penurunan selama 10 tahun terakhir (World Bank, 2018). Hal ini disebabkan karena Brunei adalah negara penghasil minyak terbesar keempat di Asia Tenggara dan juga eksportir gas alam terbesar ke9 di dunia. Brunei memiliki ketergantungan yang tinggi akan migas dengan 95\% komoditas ekspor 
Brunei adalah migas. Migas menyumbang $90 \%$ pendapatan pemerintah, jauh lebih besar dibandingkan pemasukan dari jasa, konstruksi, agrikultur, dan bidang-bidang lainnya. Fluktuatifnya harga minyak dunia memberi efek langsung terhadap perekonomian Brunei.

\section{Perkembangan Infrastruktur Laut ASEAN+3 Tahun 2007-2017}

Anggaran infrastruktur dalam Anggaran Pendapatan dan Belanja Negara (APBN) mengalami peningkatan setiap tahun semenjak pemerintahan Presiden Jokowi. Tahun 2014 anggaran infrastruktur adalah 178 triliun, tahun 2015 meningkat menjadi 290 triliun, tahun 2016 meningkat kembali menjadi 317 triliun dan tahun 2017 meningkat menjadi 440.9 triliun. Salah satu kebijakan belanja negara pada tahun 2017 adalah meningkatkan belanja produktif seperti infrastruktur dan konektivitas. Target pembangunan infrastruktur tahun 2017 adalah membangun jalan sepanjang $836 \mathrm{~km}$, jembatan sepanjang $10198 \mathrm{~km}, 13$ bandara baru, pembangunan/pengembangan fasilitas pelabuhan di 61 lokasi, pembangunan jalur kereta api sepanjang $710 \mathrm{~km}$ dan pembangunan terminal penumpang di tiga lokasi.
Tahun 2013 negara didunia menghabiskan 14\% dari total GDP dunia yaitu 9.6 triliun USD untuk membangun infrastruktur, dimana pembangunan untuk jalan, pelabuhan, bandara, jalur kereta api dan jaringan telekomunikasi menghabiskan 2.5 triliun USD (26\%). Pembangunan infrastruktur memiliki tingkat pengembalian sosial ekonomi sekitar 20\%, dimana satu dolar investasi infrastruktur dapat meningkatkan PDB dan dapat meningkatkan produktivitas dalam jangka panjang (McKinsey Global Institute).

Container port traffic (CPT) merupakan indeks yang mengukur arus lalu lintas kontainer dari darat ke moda transportasi laut. TEU adalah satuan standar yang dipakai. Semakin banyak jumlah kontainer yang singgah disuatu pelabuhan artinya pelabuhan negara tersebut besar dan efisien (murah) untuk menampung banyak kontainer. Penelitian Dundovic dan Hess (2005) menunjukkan bahwa kapasitas terminal sangat bergantung kepada kemampuan peralatan pelabuhan dalam melakukan bongkar muat. CPT adalah variabel yang menggambarkan kualitas infrastruktur pelabuhan.

Tabel 2. Jumlah Container Port Traffic ASEAN+3 Tahun 2007 - 2017 (Juta TEUs)

\begin{tabular}{lrrrrrr}
\hline Negara & $\mathbf{2 0 0 7}$ & $\mathbf{2 0 0 9}$ & $\mathbf{2 0 1 1}$ & $\mathbf{2 0 1 3}$ & $\mathbf{2 0 1 5}$ & $\mathbf{2 0 1 7}$ \\
\hline Brunei Darussalam & - & 0.09 & 0.11 & 0.12 & 0.13 & 0.12 \\
Kamboja & 0.25 & 0.21 & 0.22 & 0.23 & 0.39 & 0.49 \\
RRT & 103.82 & 108.80 & 157.42 & 175.94 & 195.28 & 213.72 \\
Indonesia & 6.58 & 7.26 & 10.41 & 11.86 & 11.98 & 13.86 \\
Jepang & 19.16 & 16.29 & 19.17 & 21.05 & 20.58 & 21.90 \\
Korea Selatan & 17.09 & 15.70 & 21.54 & 23.71 & 25.35 & 27.43 \\
Malaysia & 14.83 & 15.92 & 20.06 & 21.38 & 24.26 & 24.72 \\
Myanmar & 0.17 & 0.16 & 0.38 & 0.57 & 0.83 & 1.07 \\
Filipina & 4.35 & 4.31 & 5.31 & 5.83 & 7.21 & 8.20 \\
Singapura & 28.77 & 26.59 & 30.65 & 33.39 & 31.71 & 33.60 \\
Thailand & 6.34 & 5.90 & 8.30 & 8.89 & 9.52 & 10.73 \\
Vietnam & 4.01 & 4.94 & 6.53 & 8.97 & 11.48 & 12.28 \\
\hline
\end{tabular}

Sumber: World Bank (2018)

Ukuran pelabuhan sangat menentukan berapa banyak jumlah kontainer yang dapat ditampung. CPT negara-negara kawasan ASEAN+3 cenderung meningkat setiap tahunnya, hal ini juga terjadi di Indonesia. Indeks logistik Indonesia meningkat dari peringkat ke-63 di tahun 2016 menjadi peringkat ke-46 di tahun
2018. Hingga tahun 2018 telah terbangun 19 pelabuhan di Indonesia, delapan pelabuhan sedang dalam tahap pembangunan yang diperkirakan selesai tahun 2019, tambahan lima unit kapal penyebrangan penumpang, tambahan tiga unit kapal motor penyebrangan dan tambahan 10 pelabuhan penyebrangan. Melalui 
pembangunan pelabuhan ini kapasitas pengangkutan barang meningkat dari sebelumnya di tahun 2014 sebesar 16.7 juta TEUs/tahun menjadi 19.7 juta TEUs/tahun di tahun 2017. Pembangunan infrastruktur laut mulai terlihat manfaatnya dalam menunjang produktivitas dari pertumbuhan rata-rata per tahun dari 2014-2017 untuk angkutan barang melalui pelabuhan yaitu 3\% (Laporan Presiden RI, 2019).

Negara RRT adalah yang negara paling unggul dalam perkembangan infrastruktur CPT diantara negara ASEAN+3 lainnya. Tahun 2007 negara ini dapat menampung 104 juta TEUs kontainer dan ditahun 2017 angka tersebut meningkat lebih dari dua kali lipat menjadi 214 juta TEUs. Ukuran pelabuhan menentukan kualitas suatu pelabuhan. Pembangunan infrastruktur memiliki tingkat pengembalian sosial ekonomi sekitar 20\%, dimana 1 USD investasi infrastruktur dapat meningkatkan PDB dan dapat meningkatkan produktivitas dalam jangka panjang (McKinsey Global Institute). Semakin besar dan semakin luas sebuah terminal pelabuhan maka pelabuhan tersebut dapat menampung lebih banyak kontainer. Penelitian
Dundovic et al. (2005) yang menunjukkan bahwa kapasitas terminal sangat bergantung kepada kemampuan peralatan pelabuhan dalam melakukan bongkar muat sehingga semakin cepat waktu untuk bongkar muat (dwelling time) akan membuat biaya lebih murah sehingga dapat meningkatkan total perdagangan.

\section{Perkembangan Infrastruktur Udara ASEAN+3 tahun 2007-2017}

Pembangunan bandara masuk dalam daftar proyek strategis nasional yang terbagi menjadi tiga kategori yatu; (1) proyek pembangunan bandar udara baru, (2) Proyek revitalisasi bandara, (3) Proyek bandar udara strategis lainnya. Hingga tahun 2018 telah terbangun 10 bandara baru serta revitalisasi dan pengembangan 408 bandara di daerah rawan bencana, terisolasi dan wilayah perbatasan. Pembangunan jembatan udara melalui angkutan udara perintis kargo membawa dampak pada penurunan disparitas harga lima bahan kebutuhan pokok sebesar $57.21 \%$ untuk masyarakat daerah terpencil dan daerah tertinggal atau daerah yang belum terlayani moda transportasi lain.

Tabel 3. Jumlah Air Traffic Freight ASEAN+3 Tahun 2007 - 2017 (Ratus Juta ton - km)

\begin{tabular}{lrrrrrr}
\hline Negara & $\mathbf{2 0 0 7}$ & $\mathbf{2 0 0 9}$ & $\mathbf{2 0 1 1}$ & $\mathbf{2 0 1 3}$ & $\mathbf{2 0 1 5}$ & $\mathbf{2 0 1 7}$ \\
\hline Kamboja & 0.02 & 0.01 & 0.00 & 0.01 & 0.02 & 0.01 \\
Brunei Darussalam & 1.16 & 0.90 & 1.50 & 1.28 & 1.15 & 1.33 \\
RRT & 111.90 & 119.76 & 167.65 & 160.54 & 198.06 & 233.24 \\
Indonesia & 4.85 & 2.77 & 7.54 & 7.68 & 7.59 & 10.56 \\
Jepang & 84.35 & 104.86 & 65.46 & 77.16 & 86.62 & 106.85 \\
Korea Selatan & 90.40 & 151.63 & 123.82 & 111.13 & 112.94 & 110.02 \\
Malaysia & 26.62 & 28.53 & 21.93 & 21.62 & 20.06 & 12.62 \\
Myanmar & 0.03 & 0.03 & 0.04 & 0.03 & 0.03 & 0.05 \\
Filipina & 2.86 & 2.27 & 4.70 & 3.26 & 6.05 & 7.57 \\
Singapura & 79.56 & 73.91 & 73.01 & 63.60 & 63.32 & 70.07 \\
Thailand & 24.55 & 21.33 & 28.71 & 26.40 & 21.37 & 23.93 \\
Vietnam & 2.58 & 3.12 & 4.75 & 4.97 & 3.84 & 4.53 \\
\hline
\end{tabular}

Sumber: World Bank (2018)

Pembangunan infrastruktur udara mulai terlihat manfaatnya dalam menunjang produktivitas dari pertumbuhan rata-rata per tahun dari 2014-2017 untuk angkutan barang melalui angkutan udara yaitu $2.7 \%$. Meski masuk dalam proyek strategis nasional, pembangunan bandara belum masuk dalam daftar proyek prioritas untuk KPPIP. Kriteria pemilihan proyek prioritas diatur pada pasal 5 Perpres 75 tahun
2014 jo. Perpres 122 tahun 2016. Air traffic freight (ATF) adalah volume pengiriman barang yang dilakukan pada setiap tahap penerbangan (pengoperasian pesawat terbang dari lepas landas ke pendaratan berikutnya), diukur dalam metrik ton kali kilometer yang ditempuh. ATF adalah variabel yang menggambarkan kualitas infrastruktur bandara (quality of air transport infrastructure). Berdasarkan data pada Tabel 3 
negara dengan kemampuan daya angkut barang melalui transportasi udara paling tinggi adalah RRT, Jepang dan Korea Selatan sedangkan yang paling kecil daya angkutnya adalah Kamboja, Myanmar dan Brunei Darussalam.

Tahun 2007 daya angkutnya masih berada di angka 4.85 ratus juta ton - $\mathrm{km}$ dan meningkat lebih dari dua kali lipat di tahun 2017 menjadi 10.56 ratus juta ton $-\mathrm{km}$. Meski masuk dalam proyek strategis nasional, pembangunan bandara belum masuk dalam daftar proyek prioritas untuk Komisi Percepatan Penyediaan Infrastruktur Prioritas (KPPIP). Hal ini didorong karena aktivitas ekspor-impor menggunakan bandara sebagai moda transportasi sangat minim yaitu kurang dari 3\%. Aktivitas ekspor-impor melalui bandara paling tinggi di negara RRT, Korea Selatan dan Jepang sedangkan yang paling sedikit adalah Kamboja, Myanmar dan Brunei Darussalam (World Bank, 2018).

\section{Perkembangan Internet ASEAN+3 Tahun 2007-2017}

Globalisasi dan perkembangan informasi dan teknologi komunikasi (ICT) berkontribusi signifikan terhadap perekonomian dunia. Perkembangan ICT mendorong tumbuhnya inovasi-inovasi baru yang berdampak pada meningkatnya nilai perdagangan suatu negara dengan negara mitranya. Perkembagan ICT juga berdampak pada menurunnya biaya komunikasi sehingga membuat jarak geografi tidak lagi berpengaruh terhadap perdagangan. Sektor ICT berkembang pesat selama 20 tahun terakhir dan permintaan barang dan jasa untuk sektor ICT baik dari rumah tangga, sektor bisnis maupun pemerintah tumbuh dengan signifikan (Yushkova, 2013).

Tabel 4. Persentase Pengguna Internet ASEAN+3 Tahun 2007 - 2017

\begin{tabular}{lrrrrrr}
\hline \multicolumn{1}{c}{ Negara } & $\mathbf{2 0 0 7}$ & $\mathbf{2 0 0 9}$ & $\mathbf{2 0 1 1}$ & $\mathbf{2 0 1 3}$ & $\mathbf{2 0 1 5}$ & $\mathbf{2 0 1 7}$ \\
\hline Kamboja & 0.49 & 0.53 & 3.10 & 6.80 & 22.33 & 34.00 \\
Brunei Darussalam & 44.68 & 49.00 & 56.00 & 64.50 & 71.20 & 74.64 \\
RRT & 16.00 & 28.90 & 38.30 & 45.80 & 50.30 & 54.30 \\
Indonesia & 5.79 & 6.92 & 12.28 & 14.94 & 21.98 & 32.29 \\
Jepang & 74.30 & 78.00 & 79.05 & 88.22 & 91.06 & 90.87 \\
Korea Selatan & 78.80 & 81.60 & 83.76 & 84.77 & 89.90 & 95.10 \\
Malaysia & 55.70 & 55.90 & 61.00 & 57.06 & 71.06 & 80.14 \\
Myanmar & 0.22 & 0.22 & 0.98 & 8.00 & 21.73 & 25.47 \\
Singapur & 69.90 & 69.00 & 71.00 & 80.90 & 79.01 & 84.45 \\
Thailand & 20.03 & 20.10 & 23.67 & 28.94 & 39.32 & 52.89 \\
Vietnam & 20.76 & 26.55 & 35.07 & 38.50 & 43.50 & 48.11 \\
Filipina & 5.97 & 9.00 & 29.00 & 48.10 & 53.70 & 59.52 \\
\hline Sin & & & & & &
\end{tabular}

Sumber: World Bank (2018)

Pengguna internet adalah individu yang telah menggunakan internet (dari seluruh lokasi baik dari dalam rumah maupun dari tempat lainnya) dalam tiga bulan terakhir. Internet dapat digunakan melalui komputer, perangkat mobile ataupun perangkat lainnya. Pengguna internet diseluruh negara ASEAN+3 terus mengalami peningkatan setiap tahun. Peningkatan signifikan terjadi di Filipina dimana pada tahun 2007 pengguna internet di negara ini hanya $5.97 \%$ dan ditahun 2017 menjadi 59.52\%. Peningkatan pengguna di RRT juga cukup tinggi dari $16 \%$ di tahun 2007 menjadi $54.30 \%$ di tahun 2017. Untuk Indonesia sendiri ditahun 2007 pengguna internet masih berada di angka $5.79 \%$ dan ditahun 2017 menjadi 32.29\%. Negara yang paling tinggi pengguna internetnya adalah Korea Selatan 95.10\%, Jepang 90.87\% dan Singapura $84.45 \%$. Sedangkan negara yang masih rendah pengguna internetnya yaitu Myanmar 25.47\%, Indonesia $32.29 \%$ dan Kamboja 34\% (World Bank, 2018). Koneksi internet di Indonesia masih berada dalam kondisi buruk dalam urusan kecepatan. Indonesia berada di urutan 118 dari 136 negara di dunia dalam hal kecepatan unduhan pada perangkat seluler pada Februari 2019. Internet masih menjadi masalah di Indonesia karena belum menjangkau ke kawasan terpencil, tertinggal dan terjauh di Indonesia. 
Asosiasi Penyelenggara Jasa Internet Indonesia (APJII) menyebutkan kontribusi terbesar atas penetrasi internet di Indonesia berasal dari Pulau Jawa yaitu mencapai $55.7 \%$ dari total keseluruhan. Sementara Pulau Sumatera berada di posisi kedua dengan menyumbang penetrasi sebesar 21\%, lalu ada Pulau SulawesiMaluku-Papua 10.9\%, Pulau Kalimantan 6.6\% dan Pulau Bali dan Nusa Tenggara sebesar 5.2\%. Kualitas fasilitas perdagangan cenderung berhubungan dengan tingkat pendapatan (GDP per kapita). Negara-negara dengan GDP per kapita yang lebih tinggi umumnya memiliki peringkat lebih baik pada border process dibandingkan dengan negara yang memiliki GDP per kapita rendah (Stepherd dan Wilson, 2003). KPPIP mempunyai 37 proyek prioritas yang tersebar dari sabang sampai merauke. Salah satunya pembangunan teknologi informasi yang akan difokuskan diwilayah timur, dimana ada 10 proyek prioritas yang akan dibangun.

Jika dilihat dari nilai ekspor dan impor untuk kategori ICT, impor barang ICT Indonesia dari tahun 2007 sampai tahun 2017 nilainya berfluktuatif. Tahun 2007 impor barang ICT Indonesia adalah $4.95 \%$ dari total impor barang, dan sempat meningkat menjadi $9.68 \%$ di tahun 2008 namun setelah itu mengalami penurunan dan tahun 2017 impornya sebesar 7.6\% dari total impor barang Indonesia. Hal serupa juga terjadi pada ekspor barang ICT Indonesia. Tahun 2007 ekspor ICT Indonesia sebesar $5.28 \%$ dari total ekspor barang, dan mencapai titik tertinggi pada tahun 2009 sebesar 5.94\% lalu angka tersebut turun hingga tahun 2017 nilai ekspor barang ICT Indonesia hanya mencapai $2.98 \%$.

\section{Perkembangan Telepon Genggam ASEAN+3 Tahun 2007-2017}

Akses ke layanan telekomunikasi meningkat selama dua dekade terakhir. Pertumbuhan ini terutama didorong oleh teknologi nirkabel dan liberalisasi pasar telekomunikasi, yang memungkinkan peluncuran jaringan yang lebih cepat dan lebih murah. International Telecommunication Union (ITU) memperkirakan bahwa ada sekitar 6 miliar langganan seluler secara global pada awal 2010-an. Komunikasi seluler memiliki dampak yang sangat penting di daerah pedesaan. Mobilitas, kemudahan penggunaan, penyebaran yang fleksibel, dan biaya peluncuran teknologi nirkabel yang relatif rendah memungkinkan mereka untuk menjangkau populasi pedesaan dengan tingkat pendapatan dan melek huruf yang rendah. Perkembangan telepon seluler yang cepat dan perluasan internet secara global mendorong teknologi informasi dan komunikasi semakin diakui sebagai alat penting untuk pembangunan, berkontribusi pada integrasi global dan meningkatkan efektivitas, efisiensi, dan transparansi sektor publik serta berperan penting dalam perdagangan (World Bank, 2018)

Tabel 5. Pengguna Telepon Genggam ASEAN+3 Tahun 2007 - 2017 (\%)

\begin{tabular}{lrrrrrr}
\hline Negara & $\mathbf{2 0 0 7}$ & $\mathbf{2 0 0 9}$ & $\mathbf{2 0 1 1}$ & $\mathbf{2 0 1 3}$ & $\mathbf{2 0 1 5}$ & $\mathbf{2 0 1 7}$ \\
\hline Brunei Darussalam & 97.672 & 107.585 & 112.474 & 115.552 & 110.979 & 127.067 \\
RRT & 40.941 & 55.265 & 72.122 & 88.886 & 92.481 & 104.582 \\
Kamboja & 18.888 & 44.485 & 94.629 & 134.893 & 134.367 & 116.042 \\
Indonesia & 40.082 & 68.387 & 101.668 & 124.280 & 131.293 & 173.840 \\
Jepang & 83.529 & 90.455 & 103.312 & 115.255 & 125.462 & 133.450 \\
Korea Selatan & 90.434 & 97.094 & 105.553 & 108.993 & 116.487 & 124.865 \\
Malaysia & 87.685 & 109.196 & 128.029 & 144.765 & 143.553 & 133.880 \\
Filipina & 64.221 & 81.963 & 98.858 & 104.410 & 115.850 & 110.396 \\
Singapura & 125.178 & 138.652 & 150.585 & 157.403 & 148.739 & 148.240 \\
Vietnam & 52.421 & 112.172 & 142.356 & 135.233 & 128.590 & 125.618 \\
Thailand & 80.026 & 98.610 & 114.688 & 137.723 & 149.935 & 176.035 \\
Myanmar & 0.504 & 1.008 & 2.460 & 13.280 & 78.227 & 89.846 \\
\hline
\end{tabular}

Sumber: World Bank (2018) 
Dampak penggunaan telepon seluler yang signifikan terhadap perdagangan adalah meningkatkan konektivitas. Penggunaan telepon genggam di wilayah ASEAN+3 mengalami peningkatan sepanjang tahun 2007-2017. Peningkatan penggunaan telepon genggam paling besar di negara Indonesia, dimana pada tahun 2007 penggunanya berjumlah 40.08 per-100 orang dan tahun 2017 menjadi 173.84 per 100 orang. Peringkat kedua ada negara Kamboja yang sebelumnya pada tahun 2007 penggunanya berjumlah 18.88 per 100 orang dan tahun 2017 menjadi 116.04 per 100 orang. Peningkatan penggunaan telepon genggam paling kecil terjadi di Singapura dan Brunei Darussalam, hal ini dikarenakan sejak tahun 2007 jumlah penggunanya sudah banyak dibanding dengan negara ASEAN+3 lainnya sehingga angka pertumbuhannya terlihat kecil jika dibandingkan dengan negara lain. Tahun 2017 negara Thailand, Indonesia dan Singapura adalah negara-negara yang penggunaan telepon genggamnya paling tinggi di antara negara ASEAN+3 (World Bank, 2018)

\section{Hasil Analisis Gravity Model}

Data pada Tabel 6 menginformasikan bahwa pada model ekspor variabel yang memiliki pengaruh signifikan positif terhadap ekspor Indonesia ke kawasan ASEAN+3 adalah jarak ekonomi, container port traffic Indonesia dan penggunaan telepon genggam Indonesia sedangkan GDP per kapita riil negara tujuan berpengaruh signifikan negatif. Pada model impor variabel yang memiliki pengaruh signifikan positif terhadap impor Indonesia ke kawasan ASEAN+3 adalah GDP per kapita riil negara tujuan, jarak ekonomi, container port traffic Indonesia, penggunaam telepon genggam Indonesia dan penggunaan internet di Indonesia. Variabel air traffic freight tidak berpengaruh pada model ekspor dan impor. Dilihat dari nilai probabilitas dan koefisien, variabel yang paling berpengaruh terhadap model ekspor adalah jarak ekonomi sedangkan untuk model impor adalah GDP per kapita negara tujuan dan variabel infrastruktur yang paling berpengaruh terhadap model ekspor dan impor adalah CPT.

Tabel 6. Hasil Olahan Model Ekspor dan Impor dengan Data Panel

\begin{tabular}{|c|c|c|c|c|c|c|}
\hline \multirow{2}{*}{ Variabel } & \multicolumn{3}{|c|}{ Ekspor } & \multicolumn{3}{|c|}{ Impor } \\
\hline & Koefisie & & Prob & Koefisie & & Prob \\
\hline C & -9.369350 & & 0.0316 & -21.0857 & & 0.0493 \\
\hline $\operatorname{lnGDPj}$ & -0.379488 & $*$ & 0.0796 & 1.635586 & $* * *$ & 0.000 \\
\hline $\operatorname{lnDIST}$ & 1.045094 & $* * *$ & 0.0000 & 1.030036 & $* * *$ & 0.0001 \\
\hline $\ln \mathrm{ATFi}$ & -0.027346 & & 0.9326 & -1.05919 & & 0.1606 \\
\hline $\operatorname{lnCPTi}$ & 0.923274 & $* * *$ & 0.0000 & 1.18846 & $* * *$ & 0.0005 \\
\hline $\operatorname{lnMP}$ & 0.119390 & $* * *$ & 0.0004 & 0.139428 & * & 0.0608 \\
\hline IU & - & & - & 0.031823 & $* * *$ & 0.0000 \\
\hline \multicolumn{7}{|c|}{ Weighted Statistics } \\
\hline$R$-square & \multicolumn{3}{|c|}{0.649043} & \multicolumn{3}{|c|}{0.556022} \\
\hline $\operatorname{Prob}(F$-statistic $)$ & \multicolumn{3}{|c|}{0.000000} & \multicolumn{3}{|c|}{0.000000} \\
\hline Sum squared resid & \multicolumn{3}{|c|}{4.531662} & \multicolumn{3}{|c|}{22.47918} \\
\hline Durbin-Watson stat & \multicolumn{3}{|c|}{0.738291} & \multicolumn{3}{|c|}{0.755184} \\
\hline \multicolumn{7}{|c|}{ Unweighted Statistics } \\
\hline$R$-square & \multicolumn{3}{|c|}{0.536622} & \multicolumn{3}{|c|}{0.600235} \\
\hline Sum squared resid & \multirow{2}{*}{\multicolumn{3}{|c|}{$\begin{array}{l}184.8438 \\
0.018100\end{array}$}} & \multirow{2}{*}{\multicolumn{3}{|c|}{$\begin{array}{l}308.4295 \\
0.055040\end{array}$}} \\
\hline Durbin-Watson stat & & & & & & \\
\hline
\end{tabular}

Keterangan: Signifikan pada taraf nyata $1 \%(* * *) ; 5 \%(* *) ; 10 \%(*)$

\section{Analisis Keberhasilan Integrasi Ekonomi Indonesia ke Kawasan ASEAN+3}

Rasio keberhasilan integrasi ASEAN+3 pada aliran ekspor Indonesia tertinggi dicapai saat
Indonesia melakukan ekspor ke Singapura di tahun 2008 dengan nilai rasio 1.51 (tabel 8). Kualitas sumber daya manusia Singapura yang sangat baik dalam menunjang produksi barang dan jasa mendorong produktivitas yang 
dimilikinya tinggi. Singapura merupakan penggerak utama liberalisasi perdagangan di ASEAN dan lebih gencar dalam melaksanakan kesepakatan Free Trade Area (FTA) dengan berbagai negara di dunia (Ridwan, 2011). Rasio keberhasilan terendah terjadi saat Indonesia ekspor ke Brunei di tahun 2007 dengan nilai rasio 0.80 .

Keberhasilan integrasi ekonomi terjadi sepanjang tahun dari 2007-2017 saat Indonesia melakukan ekspor ke Singapura dan Malaysia. Sedangkan dengan Kamboja dan Korea Selatan nilai keberhasilannya cenderung berfluktuatif. Keberhasilan integrasi dengan beberapa negara lainnya seperti Thailand, Filipina, Vietnam, Myanmar, Jepang, Brunei dan RRT belum tercapai. Perdagangan Indonesia paling tinggi adalah dengan negara RRT, namun setelah dianalisis tingginya nilai dan volume perdagangan antar kedua negara ini tidak membuat aliran dagangnya mencapai keberhasilan integrasi. Rasio keberhasilan integrasi ASEAN+3 pada aliran impor Indonesia tertinggi dicapai saat Indonesia melakukan impor ke Vietnam di tahun 2007 dengan rasio 1.92 (tabel 8). Sedangkan rasio keberhasilan terendah saat Indonesia impor ke Kamboja di tahun 2007 dimana rasionya hanya 0.10 . Keberhasilan integrasi ekonomi terjadi sepanjang tahun dari 2007-2017 saat Indonesia melakukan impor ke Vietnam, Malaysia, Singapura, Myanmar, dan Thailand. Sedangkan dengan Filipina dan Kamboja nilai keberhasilannya cenderung berfluktuatif. Keberhasilan integrasi dengan beberapa negara lainnya seperti RRT, Brunei Darussalam, Korea Selatan dan Jepang belum tercapai.

Dalam beberapa tingkatan kerjasama perdagangan yang diikuti Indonesia, kerjasama global merupakan yang paling sulit karena masih adanya proteksi berupa subsidi dan tarif. Perdagangan global masih terperangkap dalam prisoner's dilemma di mana setiap negara mencoba mempertahankan proteksi sehingga prinsip fair and free trade tidak bisa berjalan secara global. Prinsip dasar ASEAN adalah noninterference principle di mana setiap negara anggota ASEAN memiliki kebebasan untuk mengurus urusan dalam negerinya sendiri dan ASEAN tidak boleh ikut campur tangan yang membuat sifat kerjasama ASEAN menjadi intergovernmentalism, bukan supranational body seperti halnya Uni Eropa (UE). Mekanisme pengambilan keputusan di ASEAN melalui musyawarah dan mufakat bukan voting atau pemilihan suara sehingga ASEAN dikategorikan sebagai kerja kawasan lunak (soft regionalism) berbeda dengan UE yang berdasarkan hukum atau legal binding (hard-regionalism) sehingga berdampak pada kerjasama ekonomi kawasan (Verico K, 2019). Integrasi ekonomi regional ASEAN tidak berdampak pada perdagangan Indonesia karena rendahnya tingkat infrastruktur, penguasaan bahasa internasional, serta kurang populernya bahasa Indonesia di kalangan internasional. 
Tabel 7. Manfaat Perjanjian ASEAN+3

\begin{tabular}{l}
\hline AC-FTA \\
\hline Terbukanya akses pasar produk \\
pertanian (Chapter 01-08 \\
menjadi 0\%) Indonesia ke RRT \\
pada tahun 2004.
\end{tabular}

Terbukanya akses pasar ekspor Indonesia ke RRT pada tahun 2005 yang mendapatkan tambahan $40 \%$ dari NT $( \pm 1880$ pos tarif), yang diturunkan tingkat tarifnya menjadi $0-5 \%$.

Terbukanya akses pasar ekspor Indonesia ke RRT pada tahun 2007 yang mendapatkan tambahan $20 \%$ dari NT $( \pm 940$ pos tarif), yang diturunkan tingkat tarifnya menjadi 0-5\%.
Pada tahun 2010, Indonesia akan memperoleh tambahan akses pasar ekspor ke RRT sebagai akibat penghapusan seluruh pos tarif dalam NT RRT.

Tahun $2010 \quad$ Indonesia menghapuskan 6683 pos tarif (93.39\%) dan 100 persen pada tahun 2012.
Akses pasar ekspor Indonesia ke Korea akan meningkat akibat penghapusan tarif $70 \%$ pos tarif Korea dalam Normal Track (NT).

Produk-produk yang akan dihapuskan tarifnya pada waktu implementasi, antara lain binatang hidup, ikan, sayuran, minyak sawit, produk kimia, produk kertas, tekstil dan produk tekstil, alas kaki, kulit, produk kayu dan sebagainya.

Akses pasar ekspor Indonesia ke Korea pada tahun 2008 meningkat akibat $\pm 95 \%$ pos tarif Korea dalam NT akan dihapus.

Tahun 2010, seluruh pos tariff Korea dalam NT akan dihapuskan.

Sensitive Track AKFTA mencapai 464 pos tariff (HS-6 digit) antara lain perikanan, beras, gula, wine alkohol, produk kimia, tekstil, baja komponen dan sebagainya.
Akses pasar ekspor Indonesia ke Jepang akan meningkat: (i) 7287 pos tariff (80\%) di Jepang akan bebas bea masuk; (ii) bebas bea masuk akan meningkat hingga $90 \%$ total pos tarif dalam lima tahun kedepan.

Dalam Persetujuan AJCEP jumlah Exclusion List Jepang sebesar 627 pos tarif atau lebih rendah dibandingkan Persetujuan IJEPA (886 pos tarif).

Jepang memberikan komitmen dalamp persetujuan AJCEP untuk 363 pos tarif seperti ikan dan produk perikanan, sayuran, buah tropis, jus, kakao, makanan olahan, minyak dan gas, kulit dan produk kulit, kayu lapis, kertas \& produk kertas, alas kaki, perhiasan dsb.

Meningkatkan investasi Jepang di Indonesia, saat ini Jepang termasuk salah satu negara investor terbesar Indonesia dan mendorong terjadinya alih teknologi.

Meningkatkan akses pasar Indonesia ke Jepang baik dari segi perdagangan barang maupun jasa (tenaga kerja).

Sumber: Kemenperin (2018). 
Tabel 8. Analisis keberhasilan integrasi ekonomi dalam ekspor

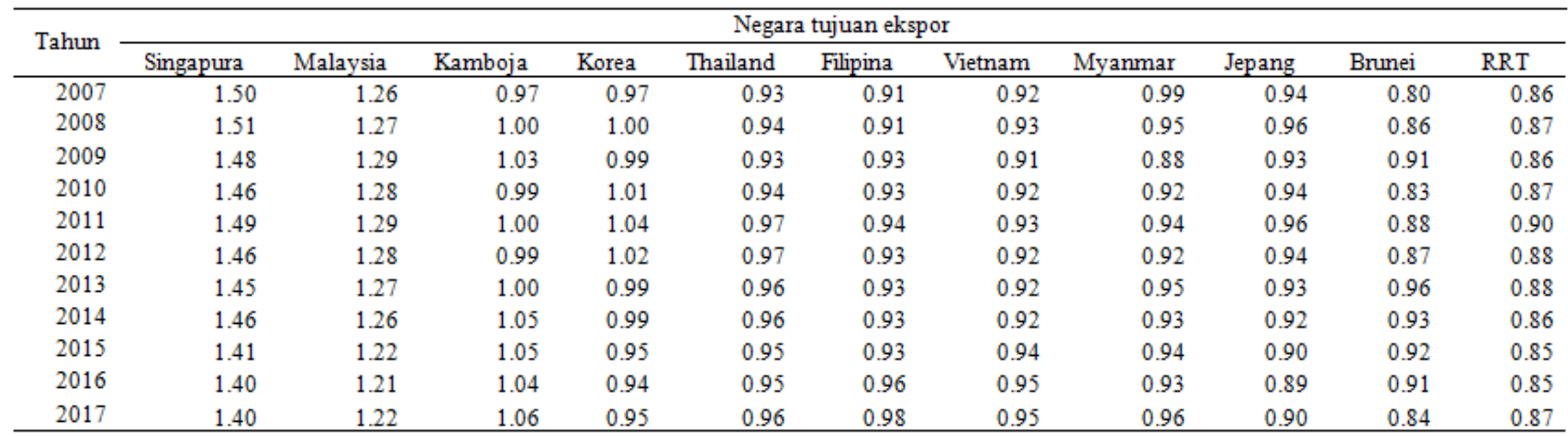

Tabel 9. Analisis keberhasilan integrasi ekonomi dalam impor

\begin{tabular}{|c|c|c|c|c|c|c|c|c|c|c|c|}
\hline \multirow{2}{*}{ Tahun } & \multicolumn{11}{|c|}{ Negara asal impor } \\
\hline & Vietnam & Malaysia & Singapura & Myanmar & Thailand & Filipina & Kamboja & RRT & Korea & Brunei & Jepang \\
\hline 2007 & 1.64 & 1.35 & 1.04 & 1.92 & 1.04 & 0.91 & 0.10 & 0.95 & 0.84 & 0.96 & 0.67 \\
\hline 2008 & 1.40 & 1.38 & 1.15 & 1.38 & 1.05 & 0.98 & 0.40 & 0.98 & 0.91 & 1.02 & 0.74 \\
\hline 2009 & 1.37 & 1.33 & 1.12 & 1.25 & 1.02 & 0.95 & 0.71 & 0.97 & 0.88 & 0.87 & 0.72 \\
\hline 2010 & 1.39 & 1.30 & 1.12 & 1.18 & 1.03 & 0.99 & 0.36 & 0.95 & 0.89 & 0.85 & 0.74 \\
\hline 2011 & 1.53 & 1.33 & 1.09 & 1.22 & 1.07 & 1.03 & 0.88 & 0.98 & 0.94 & 0.91 & 0.75 \\
\hline 2012 & 1.48 & 1.33 & 1.07 & 1.08 & 1.05 & 1.01 & 0.93 & 0.97 & 0.91 & 0.79 & 0.76 \\
\hline 2013 & 1.46 & 1.27 & 1.08 & 1.05 & 1.03 & 1.03 & 1.03 & 0.96 & 0.90 & 0.87 & 0.75 \\
\hline 2015 & 1.47 & 1.26 & 1.03 & 1.22 & 1.04 & 1.01 & 1.20 & 0.95 & 0.87 & 0.69 & 0.73 \\
\hline 2016 & 1.48 & 1.27 & 1.03 & 1.13 & 1.07 & 1.03 & 1.39 & 0.95 & 0.86 & 0.71 & 0.73 \\
\hline 2017 & 1.46 & 1.28 & 1.03 & 1.12 & 1.09 & 1.07 & 1.37 & 0.95 & 0.87 & 0.59 & 0.74 \\
\hline
\end{tabular}




\section{SIMPULAN DAN SARAN}

\section{Simpulan}

Nilai ekspor dan impor Indonesia dengan ASEAN+3 tinggi dan mendominasi meskipun tidak semua perdagangan memberi nilai surplus pada neraca perdagangan Indonesia. Sektor non migas masih menjadi sektor andalan. Indonesia masih banyak mengekspor barang primer dan nilai ekspor-impor terbesar Indonesia adalah dari negara RRT.

Hasil gravity model menunjukkan bahwa ekspor Indonesia ke kawasan ASEAN+3 dipengaruhi oleh GDP per kapita riil negara tujuan, jarak ekonomi, container port traffic Indonesia dan penggunaam telepon genggam Indonesia. Jarak ekonomi, container port traffic Indonesia dan penggunaam telepon genggam Indonesia memiliki pengaruh positif terhadap total ekspor Indonesia ke kawasan ASEAN+3 sedangkan GDP per kapita riil negara tujuan memiliki pengaruh negatif. Hasil gravity model impor Indonesia ke kawasan ASEAN+3 dipengaruhi oleh GDP per kapita riil negara tujuan, jarak ekonomi, container port traffic Indonesia, pengguna internet Indonesia dan penggunaam telepon genggam Indonesia. Seluruh variabel memiliki pengaruh positif terhadap total impor Indonesia ke kawasan ASEAN+3.

Hasil perhitungan rasio keberhasilan integrasi menunjukkan bahwa keberhasilan integrasi ekonomi untuk ekspor dan impor Indonesia ke kawasan ASEAN+3 belum tercapai secara sepenuhnya, meskipun potensi untuk mencapai keberhasilan sangat besar ditunjukkan oleh banyak rasio yang semuanya bernilai diatas 0.8 atau mendekati satu.

\section{Saran}

Berdasarkan hasil analisis pengaruh infrastruktur terhadap perdagangan dan keberhasilan integrasi ekonomi Indonesia ke ASEAN+3, adapun saran yang dapat diberikan adalah:

1. Jarak ekonomi memiliki hubungan positif dan signifikan terhadap aliran ekspor dan impor di kawasan ASEAN+3. Hal ini membuktikan bahwa jarak bukan lagi menjadi penghalang dalam proses perdagangan, agar ekspor-impor meningkat maka perbaikan infrastruktur terkait transportasi sangat dibutuhkan di masingmasing negara ASEAN+3, khususnya pada kualitas pelabuhan sebagai infrastruktur transportasi utama bagi perdagangan di kawasan ASEAN.

2. Container port traffic memiliki hubungan positif dan signifikan terhadap aliran ekspor dan impor di kawasan ASEAN+3. Pemerintah, swasta dan BUMN/D harus sejalan dan bekerjasama untuk kemajuan infrastruktur Indonesia. Dalam proses pambangunannya, pemerintah sebagai regulator harus tetap mengawasi masuknya bahan baku impor untuk keperluan pembangunan nasional dan dibutuhkan evaluasi dan monitoring pemerintah agar barang impor yang masuk adalah barangbarang yang tidak bisa diproduksi didalam negeri.

\section{DAFTAR PUSTAKA}

[APJII] Asosiasi Penyelenggara Jasa Internet Indonesia. Laporan Survei Penetrasi dan Profil Perilaku Pengguna Internet Indonesia Tahun 2018 [internet]. [diunduh 27 Oktober 2019]. Tersedia pada: https://www.apjii.or.id/

[BAPPENAS] Badan Perencanaan Pembangunan Nasional. Kajian evaluasi pembangunan bidang transportasi di Indonesia. Jakarta (ID): BAPPENAS.

[BPS] Badan Pusat Statistik. Bongkar Muat Barang Antar Pulau dan Luar Negeri di Pelabuhan Indonesia [internet]. [diunduh 2019 Februari 3]. Tersedia pada: https://www.bps.go.id/

Daryanto A, Sahara. 2016. The impact of logistic performance on the Indonesia agricultural export. Journal of ISSAAS. 22(2):28-39.

Dundovic, Cedomir dan Hess, Svjetlana. 2005. Exploitability of the port container terminal stacking area capacity in the 
circumstances of increased turnover. ISEP 2005.

Fejzic A, Covrk E. 2016. Infrastructure, transport costs, and Bosnia and Herzegovina's trade: a gravity model approach. Ekonomskki Vjesnik Paper. 77-90

Ismail NW, Mahyideen JM. 2015. The impact of infrastructure on trade and economic growth in selected economies in Asia. ADBI Working Paper Series No.553.

Kawai M, Naknoi K. 2015. Investment: ASEAN economic integration through trade and foreign direct investment: long-term challenges. ADBI Working Paper.

[Kemenperin RI] Kementerian Perindustrian Republik Indonesia. Dukung Penggunaan Produk Dalam Negeri. [diunduh 2019 April 22]. Tersedia pada: https://www.kemenperin.go.id

[KPPIP] Komite Percepatan Penyediaan Infrastruktur Prioritas. Proyek Prioritas. [diunduh 2019 Juni 11]. Tersedia pada: https://www.kppip.go.id

[KSP RI] Kantor Staf Presiden Republik Indonesia. Laporan 5 Tahun Bidang Ekonomi. [diunduh 2019 Juni 12]. Tersedia pada: http://presidenri.go.id

Nordas HK, Piermartini R. 2004. Infrastructure and trade. Economic Research and Statistics Division WTO.

Orzan B. 2017. Information and communications technology (ICT) and international trade: evidence from Turkey. Eurosian Economic Review. 8(1): 93-113.

Ridwan. 2011. Analisis Aliran Perdagangan dan Investasi dalam Integrasi Ekonomi ASEAN: Pendekatan Gravity Model
[Tesis]. Bogor (ID): Institut Pertanian Bogor.

Salvatore D. 2013. International Economics. Eleventh Edition. New Jersey (US): John Wiley \& Sons, Inc.

Stepherd B, Wilson J. 2008. Trade Facilitation in ASEAN Member Countries: Measuring Progrees and Assesing Priorities. Policy Research Working Paper. 20(4):367-383.

[UNCOMTRADE] United Nations Conference on Trade and Development. Data GDP 2007-2017 [internet]. [diunduh 2019 Januari 5]. Tersedia pada: https://comtrade.un.org/data/

Verico K. (2015). Indonesia in the ASEAN economic integration framework. Munich Personal RePec Archive.

[WB] World Bank. 2008. A Handbook of International Trade In Services. Oxford University Press.

[WB] World Bank. Data GDP dan Perdagangan Negara ASEAN+3 [Internet]. [diunduh 2019 Februari 27]. Tersedia pada: http://data.worldbank.org/indicator

[WEF] World Economic Forum. 2014-2018. The Global Competitiveness Report 2014-2018 [Internet]. [diunduh 2019 Januari 12]. Tersedia pada: http://www3.weforum.org

Wilson W, Blonigen BA. 2006. New measures of port efficiency using international trade data. NBER Working Paper No 12052.

Yushkova. 2013. Impact of ICT on trade in different technology groups: Analysis and implications. International Economics dan Economic Policy. 